\title{
Prevalence of stress among Iranian medical students: a questionnaire survey
}

\author{
G.M. Koochaki, ${ }^{\text {A. Charkazi, }}{ }^{2}$ A. Hasanzadeh, ${ }^{3}$ M. Saedani, ${ }^{4}$ M. Qorbani ${ }^{5}$ and A. Marjani ${ }^{6}$
}

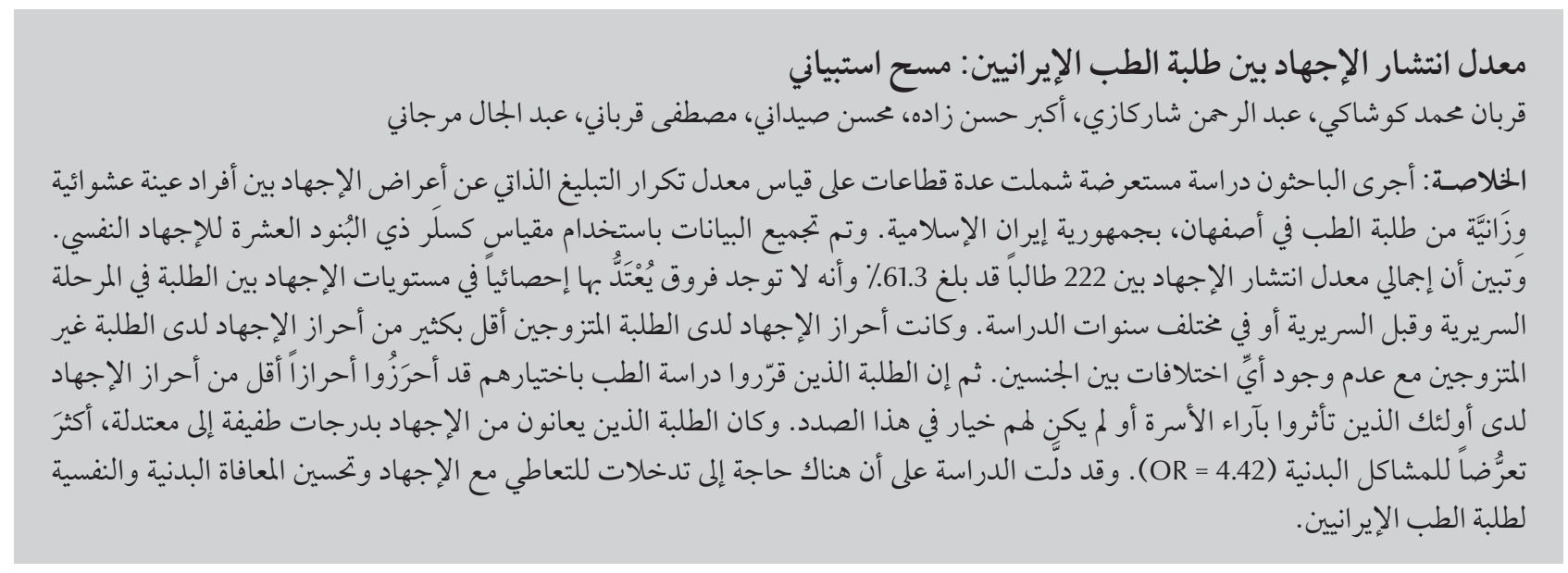

ABSTRACT A cross-sectional study measured the frequency of self-reported stress symptoms among a weighted random sample of medical students in Isfahan, Islamic Republic of Iran. The data were gathered using the Kessler 10 -item psychological distress scale. The overall prevalence of stress among 222 students was $61.3 \%$ and there were no statistically significant differences in stress levels between students in the pre-clinical and clinical phases or different years of study. Married students had significantly lower scores than single students but there were no differences between the sexes. Students who chose to study medicine had lower stress scores than those who were influenced by family or had no choice about the subject. Students with mild to moderate stress were significantly more likely to suffer physical problems $(\mathrm{OR}=4.42)$. Interventions are needed to tackle stress and improve Iranian medical students' physical and psychological well-being.

\section{Prévalence du stress chez les étudiants en médecine iraniens : une enquête par questionnaire}

RÉSUMÉ Une enquête transversale a mesuré la fréquence des symptômes de stress rapportés par les étudiants en médecine d'Ispahan (République islamique d'Iran) inclus dans un échantillon aléatoire pondéré. Les données ont été collectées aux moyens de l'Échelle de détresse psychologique de Kessler en 10 items. La prévalence globale du stress chez 222 étudiants était de 61,3 \% et aucune différence statistiquement significative n'a été observée dans le degré de stress entre les étudiants des deux premières années pré-cliniques et les étudiants des années cliniques ou des autres années d'étude. Les étudiants mariés avaient des scores nettement plus faibles que les étudiants célibataires, mais aucune différence entre les sexes n'a été relevée. Les étudiants qui avaient décidé eux-mêmes d'étudier la médecine avaient des scores de stress plus faibles que les étudiants en médecine dont le choix de carrière avait été influencé par leur famille ou qui n'avaient pas eu le choix. Les étudiants souffrant de stress léger à modéré étaient beaucoup plus susceptibles de présenter des troubles physiques (O.R. $=4,42$ ). Des interventions sont requises pour s'attaquer au stress des étudiants en médecine iraniens et améliorer leur bien-être physique et psychologique.

${ }^{2}$ Department of Surgery; ${ }^{2}$ Department of Public Health, School of Paramedicine and Health, Golestan University of Medical Sciences, Gorgan, Islamic Republic of Iran (Correspondence to A. Charkazi: r.charkazi@gmail.com).

${ }^{3}$ Department of Biostatistics and Epidemiology; ${ }^{4}$ Department of Environmental Health, School of Health, Isfahan University of Medical Sciences, Isfahan, Islamic Republic of Iran.

${ }^{5}$ Department of Community Medicine; ${ }^{6}$ Department of Biochemistry and Biophysics, Faculty of Medicine, Golestan University of Medical Sciences, Gorgan, Islamic Republic of Iran

Received: 19/11/09; accepted: 23/12/09 


\section{Introduction}

In addition to coping with the normal stressors of everyday life, medical students must deal with stressors specific to medical school. These include information and input overload, financial indebtedness, lack of leisure time, and pressures of work, work relationships and career choices [1-3]. Although some degree of stress is a normal part of medical training and can be a motivator for some individuals, not all students find stress constructive [4]. For many individuals, stress arouses feelings of fear, incompetence, uselessness, anger and guilt and can be associated with both psychological and physical morbidity [5-9]. High levels of stress may have a negative effect on mastery of the academic curriculum, by impeding concentration, problem solving, decision making, completion of work and other abilities necessary for student learning $[10,11]$.

Studies that have examined sources of stress among medical students generally point to 3 areas: academic pressures, social issues and financial problems [12]. Reported levels of stress among medical students range from $25 \%$ to $75 \%[13,14]$. In the United States, a survey of 9 medical schools found that $47 \%$ of students had at least 1 major issue related to mental health or substance use and that stress affected $26 \%$ within this group [5]. A study in 3 British universities showed that the prevalence of stress was $31.2 \%$ [2]. Other studies showed that the prevalence of stress was $41.9 \%$, $61.4 \%$ and $57 \%$ in Malaysian [14], Thai [15] and Saudi Arabian [16] medical schools respectively.

A study in the Islamic Republic of Iran showed that the prevalence of stress was $60.6 \%$ among medical students in Gorgan [17]. Nevertheless, there are few studies in the medical schools of our country. We therefore planned this study to assess the prevalence of stress among medical students attending the medical school in Isfahan city.
This information may aid in designing appropriate intervention strategies and planning modifications in the medical curriculum to enhance students' learning abilities.

\section{Methods}

\section{Setting and sample}

At the time of the study, Isfahan medical school had a 7-year study programme. The first 2.5 years are largely pre-clinical years (basic sciences) while the later clinical years are clinical rotations in health care facilities (hospital and polyclinics).

To recruit the sample, lists of students in each class were obtained from all departments of the medical school. Through weighted random sampling to reflect the distribution of students across the 7 classes 222 medical students enrolled in Isfahan medical school during the academic year 2009 were recruited into the study. Students who reported suffering from any psychological disorder were excluded.

\section{Data collection procedure}

Data collection was performed using the Kessler 10-item psychological distress scale (K10) which was developed by Kessler et al. to measure the level of distress and severity of psychological symptoms [18]. It was designed to measure current (1-month) distress in population surveys. The K10 comprises 10 questions of the form: "how often in the past month did you feel..." and offers specific symptoms such as "tired out for no good reason", "nervous" and "sad or depressed". The 5 possible responses range from "none of the time" to "all of the time" and are scored from 1 to 5 and then summed to give a total maximum score of 50 . The cut-offscores used were those recommended by the authors: < 20 no stress; 20-24 mild stress; 25-29 moderate stress; 30-50 severe stress [18].
The K10 was translated into Farsi then its reliability was tested by Cronbach alpha in a pilot study with 30 students $(\alpha=0.91)$. The instrument used in this study included demographic data such as students' age, sex and year of study, type of living accommodation and motivation to study medicine, physical health problems (scores from $1-5$ ) and ability to work or carry out normal activities.

Data collection took place in May 2009. Questionnaires were distributed to the subjects to complete 1 month before the beginning of the examination period in order to minimize the extra stress symptoms. The students were given assurances about the confidentiality of their responses and names were not recorded. Verbal consent was obtained from the students and they were allowed to respond to the questionnaire in their own time and in privacy.

\section{Statistical analysis}

All data were entered into SPSS, version 11.5 for Windows (double entry of data was used in order to check for data entry accuracy). Normal distribution wasconfirmed by the Kolmogorov-Smirnov test for continuous variables and data analysis was performed by independent $t$-test, analysis of variance (ANOVA) using Tukey post-hoc comparisons and Pearson correlation. All other measures were subject to descriptive statistics. A $P$-value $<0.05$ was considered statistically significant.

\section{Results}

A total of 300 students entered the study and completed questionnaires were received from 222 (response rate of $74.0 \%$ ). The students' demographic characteristics are shown in Table 1. There were 114 men (51.4\%) and 108 women (48.6\%). The mean (SD) age of the participants was 21.9 (SD 2.2) years, with a range of $18-30$ years. Most 


\begin{tabular}{|c|c|c|c|c|c|}
\hline Variable & No. & $\%$ & Mean (SD) stress score & Test statistic & $P$-value \\
\hline Sex & & & & $t=0.51$ & 0.960 \\
\hline Male & 114 & 51.4 & $23.6(8.2)$ & & \\
\hline Female & 108 & 48.6 & $23.6(6.3)$ & & \\
\hline Marital status & & & & $t=1.985$ & 0.048 \\
\hline Single & 208 & 93.7 & $23.8(7.2)$ & & \\
\hline Married & 14 & 6.3 & $19.8(8.0)$ & & \\
\hline Year of study & & & & $F=1.292$ & 0.262 \\
\hline $1 s t$ & 30 & 13.6 & $24.6(6.6)$ & & \\
\hline 2nd & 44 & 19.9 & $22.4(6.3)$ & & \\
\hline $3 r d$ & 41 & 18.5 & $25.1(8.2)$ & & \\
\hline 4 th & 58 & 26.2 & $22.1(6.9)$ & & \\
\hline 5 th & 18 & 8.1 & $24.3(7.0)$ & & \\
\hline 6 th & 16 & 7.4 & $25.9(7.9)$ & & \\
\hline 7th & 15 & 6.3 & $22.9(9.2)$ & & \\
\hline Academic group & & & & $t=1.051$ & 0.294 \\
\hline Pre-clinical & 100 & 45.2 & $24.1(7.2)$ & & \\
\hline Clinical & 122 & 54.8 & $23.2(7.4)$ & & \\
\hline Living accommodation & & & & $F=1.579$ & 0.209 \\
\hline Dormitory & 167 & 75.2 & $23.9(7.1)$ & & \\
\hline Parental home & 51 & 23.0 & $22.3(7.6)$ & & \\
\hline Rented accommodation & 4 & 1.8 & $27.5(8.5)$ & & \\
\hline Motivation to study medicine & & & & $F=3.456^{\mathrm{a}}$ & 0.033 \\
\hline Interested & 168 & 75.7 & $22.9(6.6)$ & & \\
\hline Family influenced choice & 9 & 4.1 & $26.2(10.0)$ & & \\
\hline No choice & 45 & 20.2 & $25.8(8.4)$ & & \\
\hline
\end{tabular}

${ }^{a}$ ANOVA test.

$S D=$ standard deviation

of the respondents (75.2\%) lived in halls of residence.

The mean K10 score of the participants was 23.5 (SD 7.2) out of a maximum of 50 . The score range was 10-48. The prevalence of stress of all types among the medical students was $61.3 \%$ (18.0\% suffered mild stress, $22.5 \%$ moderate stress and $20.8 \%$ severe stress) (Table 2).

There was no statistically significant difference in the stress levels between pre-clinical and clinical students $(t=$ $1.051, P=0.294)$ (Table 1). There was also no significant correlation of mean stress scores across different years of study $(F=1.292, P=0.262)$ or between the sexes $(t=0.51, P=0.960)$. A significant differenced was observed between stress score and marital status ( $t=1.985$, $P=0.048)$. ANOVA showed no difference between the students' type of accommodation and mean stress scores $(F=1.579, P=0.209)$. The relationship with motivation to study and stress levels were significant $(F=3.456, P=$ 0.033 ) and students who mentioned no choice about studying had higher mean scores on stress.

Table 3 shows that themean number of days that students were unable to work was 4.6. The mean value was significantly higher among students who had scores above the cut-off for stress than those below the cut-off ( 6.2 days versus 1.9 days). The mean number of days their work was reduced was 3.8 and this was also significantly higher among students with stress than without stress (4.9 days versus 2.0 days).

The overall prevalence of self-reported physical problems was $19.4 \%$; $4.5 \%$ of students reported having severe problems and $14.9 \%$ had mild to moderate problems. This difference was statistically significant comparing students with and without stress $(F=9.451, P<$ 0.001 ). The odds ratio shows that the risk of suffering stress was more than 4 times higher for students with mild to moderate stress (OR $=4.42,95 \% \mathrm{CI}$ : $1.63-11.98, P=0.003)$ compared with students with no physical problems. Students with severe physical problems were also 3 times more likely to suffer stress but this was not statistically significant $(\mathrm{OR}=3.16,95 \% \mathrm{CI}: 0.65-15.30$, 


\begin{tabular}{lccc}
\hline $\begin{array}{l}\text { Table } 2 \text { Distribution of medical students according to their scores on the Kessler } \\
\text { 10-item psychological distress scale (K10) }\end{array}$ & & \\
\hline Classification & K10 cut-off scores & No. & $\%$ \\
No stress & $<20$ & 86 & 38.7 \\
Mild stress & $20-24$ & 40 & 18.0 \\
Moderate stress & $25-29$ & 50 & 22.5 \\
Severe stress & $30-50$ & 46 & 20.8 \\
Total & & 222 & 100.0 \\
\hline
\end{tabular}

$P=0.153)$ (Table 4). Almost all the respondents with physical health problems (93.7\%) had not sought medical care for the problem.

\section{Discussion}

The results of this study revealed high levels of stress among medical students in Isfahan. The overall prevalence of scores above the cut-off for stress was $61.3 \%$, which is similar to another study in the Islamic Republic of Iran [17] and a study in Saudi Arabia [16] (61.4\% and $57 \%$ respectively). Both of the above studies used the K10 stress scale. Another study in the Islamic Republic of Iran using a different instrument that the $\mathrm{K} 10$ reported that $44.1 \%$ of subjects had a low level of stress, $31.1 \%$ average level and 24.8\% high level of stress [19]. As reported by other researchers this high level of stress may impair students' professional effectiveness by decreasing their attention span, reducing concentration levels, affecting their decisionmaking skills and reducing their ability to establish strong physician-patient relationships and it may have a direct relationship with feelings of hopelessness [19-23].

There was no association between the year of study and stress level. The mean stress score among 1st year students was higher than among 2 nd year students but the results were not statistically significant. This finding concurs with Marjani et al.'s study in the Islamic Republic of Iran [17] and Abdulghani in Saudi Arabia [16] using the same tool. However, using different tools than the K10 Stewart et al. indicated that medical students in year 2 had higher scores of anxiety and depression than in year 1 [24] and Aktekin in Turkey reported the scores for some stressful life events for medical students were significantly higher in year 2 than year 1 [25].

We also found no difference in the stress levels between pre-clinical and clinical groups of medical students. This may because both these phases of study are stressful, albeit in different ways: in the pre-clinical course there is the stress of coping with a new course of study, adjusting to the demands of the high academic workload and fears of

$\begin{aligned} & \text { Table } 3 \text { Association between stress on the Kessler 10-item psychological distress } \\
& \text { scale (K10) and the mean number of days unable to work and days of work } \\
& \text { reduced }\end{aligned}$
\begin{tabular}{lccc} 
Stress $^{\text {a }}$ & No. & $\begin{array}{c}\text { No. of days unable to } \\
\text { work } \\
\text { Mean (SD) }\end{array}$ & $\begin{array}{c}\text { No. of days of work } \\
\text { reduced }\end{array}$ \\
No & 86 & $1.9(2.5)$ & Mean (SD) \\
Yes & 136 & $6.2(7.3)$ & $2.0(4.2)$ \\
$P$-value & & $<0.001$ & $4.9(6.3)$ \\
\hline
\end{tabular}

${ }^{a}$ Above $(\geq 20)$ or below $(<20)$ cut-off score on the K10; ${ }^{b}$ t-test. $S D=$ standard deviation failing or falling behind. In the clinical phase of study there are the stresses of relationships with consultants and of dealing with patients, disease, death and suffering.

Stress was significantly associated with students' self-reported physical problems, with higher mean stress scores among students who reported suffering from physical problems. Students who had higher levels of stress also reported significantly more days when they were unable to work and days reduced. It may due to stress causing physical problems or vice versa. Abdulghani et al. in Saudi Arabia reported similar findings [16] but Marjani et al.'s study in Islamic Republic of Iran found no statistically significant relationship between students' stress levels and physical problems [17]. In another study in the Islamic Republic of Iran stress was significantly associated with student's general health [26].

Our study showed no differences in mean stress scores between male and female students. This finding is consistent with other international studies using different tools $[1,2,5,6,27]$, although a study in Sweden showed gender differences, with women scoring higher on stress than men [10]. Esfandiari in his study in the Islamic Republic of Iran concluded that female students had more stress and that this caused undesirable effects on their general health [26]. Lower levels of stress among married students than single students in our study suggests that marriage was a protective factor for stress.

Another finding of the current study was that there was a significant relationship between the subjects' level of stress and their motivation to study in the medical field. Although this could be explained by many factors, it is logical that students who reported their motivation was interest in medicine had lower stress scores that others who reported the motivation as family coercion or no choice of subject. 


\begin{tabular}{|c|c|c|c|c|c|c|c|}
\hline \multirow[t]{3}{*}{ Physical problems } & \multicolumn{4}{|c|}{ Stress $^{a}$} & \multirow[t]{3}{*}{ OR } & \multirow[t]{3}{*}{$95 \% \mathrm{Cl}$} & \multirow[t]{3}{*}{$P$-value ${ }^{b}$} \\
\hline & \multicolumn{2}{|c|}{ No } & \multicolumn{2}{|c|}{ Yes } & & & \\
\hline & No. & $\%$ & No. & $\%$ & & & \\
\hline None & 79 & 35.6 & 100 & 45.0 & 1 & - & \\
\hline Mild to moderate & 5 & 2.3 & 28 & 12.6 & 4.42 & $1.63-11.98$ & 0.003 \\
\hline Severe & 2 & 0.9 & 8 & 3.6 & 3.16 & $0.65-15.30$ & 0.153 \\
\hline
\end{tabular}

${ }^{a}$ Above $(\geq 20)$ or below $(<20)$ cut-off score on the K10; ${ }^{b}$ Logistic regression analysis.

$O R=$ odds ratio; $C l=$ confidence interval.

Several limitations of this study restrict the generalizability of the findings. The findings are based on a selfreported questionnaire which relies on the honesty of those completing it and on subjective impressions of stress. Furthermore, we have data from only one medical school. A low rate of response was evident among the 5th, 6th and 7 th year students who were busy with clinical work.

Medical students especially those in the 1st year may benefit from better social and psychological support to cope with stress. With early diagnosis, case finding and effective psychological services, possible future illness may be prevented. Concerns about workload, performance and personal competence are particularly marked in the 1 st year of medical school $[5,8]$. Stress management programmes for 1st-year medical students may also serve as a buffer to some of those stresses in the students' future careers. Klamen reported that stress management workshops for medical students made students more aware of the current and future stresses they were facing and provided them with useful tools of stress management and personal insights [28]. In the United Kingdom, the General Medical Council recommends that medical schools should have mechanisms in place to identify symptoms of stress that might be early signs of mental illness [29]. Medical schools in the United States of America and Canada tackle the problem at an earlier stage by undertaking health promotion programmes. These have been shown to reduce the effects of stress on medical students' health and academic performance [30].
In conclusion, the results of this study suggest that interventions are needed to tackle stress and improve Iranian medical students' physical and psychological well-being. Large, prospective, multicentre studies will help to identify the associated morbidity, causes and consequences of stress among medical students in the Islamic Republic of Iran.

\section{Acknowledgements}

We are grateful to all the medical students at the Isfahan University of Medical Sciences for their cooperation during the collection of data. Also special thanks to Mr Hemmatkhah, Mrs Meir Aeez and Mrs Razaknejad without whom we would have been unable to complete this study.

\section{References}

1. Miller GD, Miller EC, Peck OC. Medical student needs assessment and student affairs programming. Journal of Medical Education, 1981, 56:518-520.

2. Firth J. Levels and sources of stress in medical students. British Medical Journal (Clinical Research Ed.), 1986, 292:1177-1180.

3. Supe AN. A study of stress in medical students at Seth G.S. Medical College. Journal of Postgraduate Medicine, 1998, 44:1-6.

4. Linn BS, Zeppa R. Stress in junior medical students: relationship to personality and performance. Journal ofMedical Education, 1984, 59:7-12

5. Guthrie EA et al. Embarking upon a medical career: psychological morbidity in first year medical students. Medical Education, 1995, 29:337-341

6. Moffat $\mathrm{KJ}$ et al. First year medical student stress and coping in a problem-based learning medical curriculum. Medical Education, 2004, 38:482-491.

7. Mosley TH Jr et al. Stress, coping, and well-being among thirdyear medical students. Academic Medicine, 1994, 69:765-767.
8. Stewart SM et al. Predicting stress in first year medical students: a longitudinal study. Medical Education, 1997, 31:163-168.

9. Park CL, Adler NE. Coping style as a predictor of health and well-being across the first year of medical school. Health Psychology, 2003, 22:627-631.

10. Dahlin M, Joneborg N, Runeson B. Stress and depression among medical students: a cross-sectional study. Medical Education, 2005, 39:594-604.

11. Byars L. Stress, anxiety, depression, and loneliness of graduate counseling students: the effect of group counseling and exercise [PhD thesis]. Texas, Texas Tech University, 2005.

12. Vitaliano PP et al. Medical school pressures and their relationship to anxiety. Journal of Nervous and Mental Disease, 1984, 172:730-736.

13. Mosley TH Jr et al. Stress, coping, and well-being among thirdyear medical students. Academic Medicine, 1994, 69:765-767.

14. Sherina MS, Rampal L, Kaneson N. Psychological stress among undergraduate medical students. Medical Journal of Malaysia, 2004, 59:207-211. 
15. Saipanish R. Stress among medical students in a Thai medical school. Medical Teacher, 2003, 25(5):502-506.

16. Abdulghani HM. Stress and depression among medical students: a cross sectional study at a medical college in Saudi Arabia. Pakistan Journal of Medical Sciences, 2008, 24:12-17.

17. Marjani A et al. Stress among medical students of Gorgan (South East of Caspian Sea), Iran. Katmandu University Medical Journal, 2008, 6:421-425.

18. Kessler RC et al. Short screening scales to monitor population prevalences and trends in non-specific psychological distress. Psychological Medicine, 2002, 32:959-976.

19. Bolhari J, Ehsan Manesh M, Karimi Keisami E. Relationship between the stressors, stress symptoms and reliance on God (Tavakkol) in medical students. Iranian Journal of Psychiatry and Clinical Psychology, 2000, 21:25-34.

20. Smith A. Stress and information processing. In: Johnston $M$ et al., eds. Stress and medical procedures. Oxford, Oxford University Press, 1990:184.

21. Askenasy JJ, Lewin I. The impact of missile warfare on selfreported sleep quality. Part 1. Sleep, 1996, 19:47-51.

22. Lehner $\mathrm{P}$ et al. Cognitive biases and time stress in team decision making. IEEE Transactions on Systems, Man, \& Cybernetics Part A: Systems \& Humans, 1997, 27(5):698-703.
23. Klein G. The effect of acute stressors on decision making. In: Driskell J, Salas E, eds. Stress and human performance. Mahwah, New Jersey, Lawrence Erlbaum, 1996:48-88.

24. Stewart SM et al. Stress and vulnerability in medical students. Medical Education, 1995, 29:119-127.

25. Aktekin M et al. Anxiety, depression and stressful life events among medical students: a prospective study in Antalya, Turkey. Medical Education, 2001, 35:12-17.

26. Esfandiari Gh.R. Stress factors and their relation with general health in students of Kurdistan University of Medical Sciences in year 1999. Scientific Journal of Kurdistan University of Medical Sciences, 2001, 18:17-21.

27. Niemi PM, Vainiomäki PT. Medical students' distress-quality, continuity and gender differences during a six-year medical programme. Medical Teacher, 2006, 28:136-141.

28. Klamen DL. The stress management workshop for medical students. Academic Psychiatry, 1997, 21:42-47.

29. Morrison J, Moffat K. More on medical student stress. Medical Education, 2001, 35:617-618.

30. Wolf TM, Randall HM, Faucett JM. A survey of health promotion programs in U.S .and Canadian medical schools. American Journal of Health Promotion, 1998, 3:33-36.

\section{Correction}

S.A. Alghanim. Self-medication practice among patients in a public health care system. Eastern Mediterranean Health Journal, 2011, 17(2):409-416. The title in the Arabic abstract should read:

$$
\text { ممارسة المداو اة الذاتية لدى المرضى في ظل وجود نظام صحي عام }
$$

